\title{
AN ANALYSIS OF STUDENTS' ANXIETY \\ IN SPEAKING LEARNING OF ENGLISH EDUCATION DEPARTMENT AT UNIVERSITY OF BANTEN JAYA
}

(A Survey Research on The Second Semester of 2019-2020 Academic Year)

\author{
Siti Nurhayati ${ }^{1}$, Ida Nuraida ${ }^{2}$ \\ University of Banten Jaya \\ Serang, Indonesia \\ stnurhayati0226@gmail.com \\ idanuraida@unbaja.ac.id
}

\begin{abstract}
This research was intended to find out the level anxiety and the factors of students' anxiety at speaking learning. This approach using qualitative research with survey research method, the subject of the research were students second-semester in the English Education Department at University of Banten Jaya. The collecting data of this research used interviews, questionnaires, and student observations through speaking lecturer. The results of the research showed that the level anxiety of students there is 65\%, which means students' anxiety 136 sat a high level. The result factors anxiety of this research there are some factors of anxiety. They are: First, speaking in front of the class. Second, students' belief about language learning. The last, lack of preparation. The writer found third factors of students' speaking anxiety at speaking learning.
\end{abstract}

Keywords: Students' Anxiety, Speaking

\section{INTRODUCTION}

Communicating with language is a necessity for every human being; using language people can share information with others. In the times, the mastery of more than one language has become an essential aspect. As a nation in the industrial era 4.0, recovering from mastering the language is increasingly high. According to (Nuraida 2018) states that as a tool of human communication, language becomes effective when a person needs to communicate with others. English is not only used as a language of instruction in the business world but also in the world of Education. 
According to Martin (2019:106)

states that if speaking anxiety is not given the right intervention can affect students' confidence to interact easily in their other academic endeavors or when they are in the field of work. Speaking occurs when a speaker uses a language actively to express and deliver meaning to interact with listeners. Mastery of speaking skills is a priority for learners of second languages and foreign languages. Students who research English as a foreign language (EFL) usually have limited opportunities to speak English outside the classroom. When speaking anxiety is experienced by students majoring in English education, the stakes are higher because they are prospective teachers; in the teaching profession, students are required to have the confidence to show their speaking skills in front of an audience; student. According to (Nuraida 2019) states that most of the studies tried to offer effective model and strategy to implement in English learning. According to Woodrow (2006:309) states that anxiety is generally classified as a trait or condition. Anxiety trait is a relatively normal character trait. A person who is afraid of nature tends to be afraid in various situations. Also, according to Woodrow (2006:309) states that anxiety experienced in communication in English can weaken and can affect students' adaptation to the target environment and ultimately the achievement of their educational goals. Anxiety is a complicated different from self-perception, feelings, beliefs and behaviors related to learning in the classroom especially in speaking English. Liu and Huang (2011) states that the increased attention is given to language learners and their affective aspects, studies in this field have confirmed that language. Anxiety is a very strong predictor of student performance among effective factors. It means anxiety can occur due to 
certain factors that cause anxiety that has different aspects.

The writer has found the problem amount students' anxiety at speaking learning. The writer was observed and ask some questions to English lecturer in speaking subject in the second semester of English Education Department at University of Banten Jaya. The writer can find from the observation about the students' problem why students are still bad especially in speaking English and it is caused by many factors that make students anxiety to speaking English at speaking learning. Different students have different skill and knowledge so on that can makes miscommunication between speaker and listener. Based on the above considerations, the research on An Analysis of Students' Anxiety in speaking learning of English Education Department at University of Banten Jaya, believed to be able to solve the problems faced by students second semester of English Education Department at the University of Banten Jaya in improving their speaking skills.

\section{METHOD}

In this research focus on students' anxiety in speaking learning of English Education Department at University of Banten Jaya, and sub focus are level anxiety at speaking learning and the factors of students' anxiety at speaking learning This research employed the qualitative research approach with survey research method. Qualitative approach was chosen because this research aims at providing an insight into the case of speaking anxiety in the $2^{\text {nd }}$ semester of English Education Department at University of Banten Jaya in 2019-2020 academic year. Specially anxiety at speaking learning. In this case, the researcher analyzes it verbatim, and arrange the results of the research naturally / according to the facts in the field. Therefore, the research case approach allowed the writer to research 
Volume 3 No. 2, August 2020

Universitas Banten Jaya

particular students in an attempt to understand the case of speaking anxiety.

\section{DATA COLLECTING TECHNIQUES}

In this research, several procedures are used to get the empirical data require. The writer used this research to analyze the students' anxiety at speaking learning, to collect data, the writer used the questionnaire, interview and observation.

\section{Observation}

Another data collection technique is observation. However, during the pandemic covid-19 the writer had difficulty to observe students while in class. So, the writer did the observation with observe speaking lecturer at second semester of English Education Department to find the data. The writer used two observation. First, observation sheet about the Indicator of Students' Behavior toward Speaking Skill. Second,
P-ISSN 2623-0062

E-ISSN 2622-9056

observation about the Factor of Students' Anxiety toward Students' Speaking Achievement. Then, the writer calculates the data to know the final indicator by percentage.

\section{Questionnaires}

The writer used a questionnaire to find out students' opinions about anxiety speaking in learning in the Department of English Education, and the type of questionnaire is a closed questionnaire sent by Whatsapp message from Google form. Questionnaire contains the questions arranged by Foreign Language Classroom Anxiety Scale (FLCAS) by Horwitz, Horwitz and Cope to know the level of students' anxiety at speaking learning, then develop into indicators and further in describing into the details of the question. Variations in types of research instruments are questionnaires or checklists. The writer chose a closed questionnaire to reveal data about 
students' anxiety at speaking learning.

Likert scale is related to questions about one's attitude towards something, for example strongly agree (SA), agree (A), neutral (N), disagree (D), strongly disagree (SD). With a Likert scale, the variables can be resized in the description in this research, making it easier for respondents to answer the questionnaire, then the rating scale is as follows:

Table 1

\section{Range Scale Score}

\begin{tabular}{cc}
\hline Alternative Answer & Score \\
\hline Strongly Agree & 5 \\
\hline Agree & 4 \\
\hline Neutral & 3 \\
\hline Disagree & 2 \\
\hline Strongly Disagree & 1 \\
\hline
\end{tabular}

Table 2

Percentage of Value

\begin{tabular}{cc}
\hline Answer & Explanation \\
\hline $0 \%-19.99 \%$ & Strongly Disagree \\
\hline $20 \%-39.99 \%$ & Disagree \\
\hline $40 \%-59.99 \%$ & Neutral \\
\hline $60 \%-79.99 \%$ & Agree \\
\hline $80 \%-100 \%$ & Strongly Agree \\
\hline
\end{tabular}

\section{Interview}

In this research, the writer used interview to know the student's response about their anxiety at speaking learning. Respondents that the writer choose are eleven students of second semester at English Education Department. Furthermore, it is a direct face to face attempt to obtain reliable and valid measures in the form of verbal responses from one or more respondents. However, due to the existence of the Covid-19 Pandemic which resulted in the interview process being a little difficult due to the impossibility of meeting each other face to face. so, the writer conducted online interviews using voice notes so that they continued to run orally. The following questions were asked:

1. What do you feel when you are in the speaking class? 
2. Do you feel nervous and anxious when you speak English in front of the class?

3. What factors make you feel nervous and anxious when speaking English?

4. How do you overcome that anxiety when speaking English in front of the class?

5. When you speak English in front of the class, what body reactions do you feel?

6. How do you feel, when your friends laugh at your mistakes in speaking English in front of the class?

\section{RESULT}

\section{The Result of Observation}

In this observation, the writer makes two stages to observe the lecturer about the state of the student while in the speaking class.

a. Lecturer's Observation

In the first stage of this observation, due to the limitations of the circumstances that occur during the research, the writer decided to make observations through the speaking lecturer by giving an observation sheet and some questions about the students' behavior and achievement when learning speaking.

Based on the result of lecturer observation on $12^{\text {nd }}$ May 2020, the writer got two findings, they are:

a. The indicator of students' behavior toward speaking skill shows $36 \%$ students always did the activities in observation aspect in the column, 
and $64 \%$ students often did activities in observation aspect in the column observation.

b. The indicator of the factor of students' anxiety toward speaking achievement shows 20\% students always get their speaking achievement with did the activities in observation aspect in the column, $20 \%$ students seldom get their speaking achievement with did the activities in observation aspect in the column, and $60 \%$ students often get their speaking achievement at speaking learning.

Table 3

The Indicator of Students' Behavior toward Speaking Skill Step One

\begin{tabular}{|c|c|c|c|c|c|}
\hline \multirow[t]{2}{*}{ No. } & \multirow{2}{*}{$\begin{array}{c}\text { Point of Observation } \\
\text { (Students Behavior in Speaking Class) }\end{array}$} & \multicolumn{4}{|c|}{ Degrees of Time } \\
\hline & & Always & Often & Seldom & Never \\
\hline 1. & The students though critically & & $\sqrt{ }$ & & \\
\hline 2. & The students has a high desire to learn & $\sqrt{ }$ & & & \\
\hline 3. & The students be brave in class & & $\sqrt{1}$ & & \\
\hline 4. & $\begin{array}{l}\text { The students gave attention when lecturer was } \\
\text { teaching in class }\end{array}$ & $\sqrt{ }$ & & & \\
\hline 5. & The students got their achievement & & $\sqrt{ }$ & & \\
\hline 6. & The students made note about the lesson & & $\sqrt{ }$ & & \\
\hline 7. & $\begin{array}{l}\text { The students actively joined the discussion in } \\
\text { class }\end{array}$ & & $\sqrt{ }$ & & \\
\hline 8. & The students were active to ask lecturer & & $\sqrt{ }$ & & \\
\hline 9. & $\begin{array}{l}\text { The students were active to answer the } \\
\text { question/task from lecturer }\end{array}$ & $\sqrt{ }$ & & & \\
\hline 10. & $\begin{array}{l}\text { The students could make a good relationship with } \\
\text { their classmates }\end{array}$ & $\sqrt{ }$ & & & \\
\hline 11. & The students gave opinion in class & & $\sqrt{ }$ & & \\
\hline
\end{tabular}


Table 4

The Focus of Students' Anxiety toward Students'

Speaking Achievement

Step Two

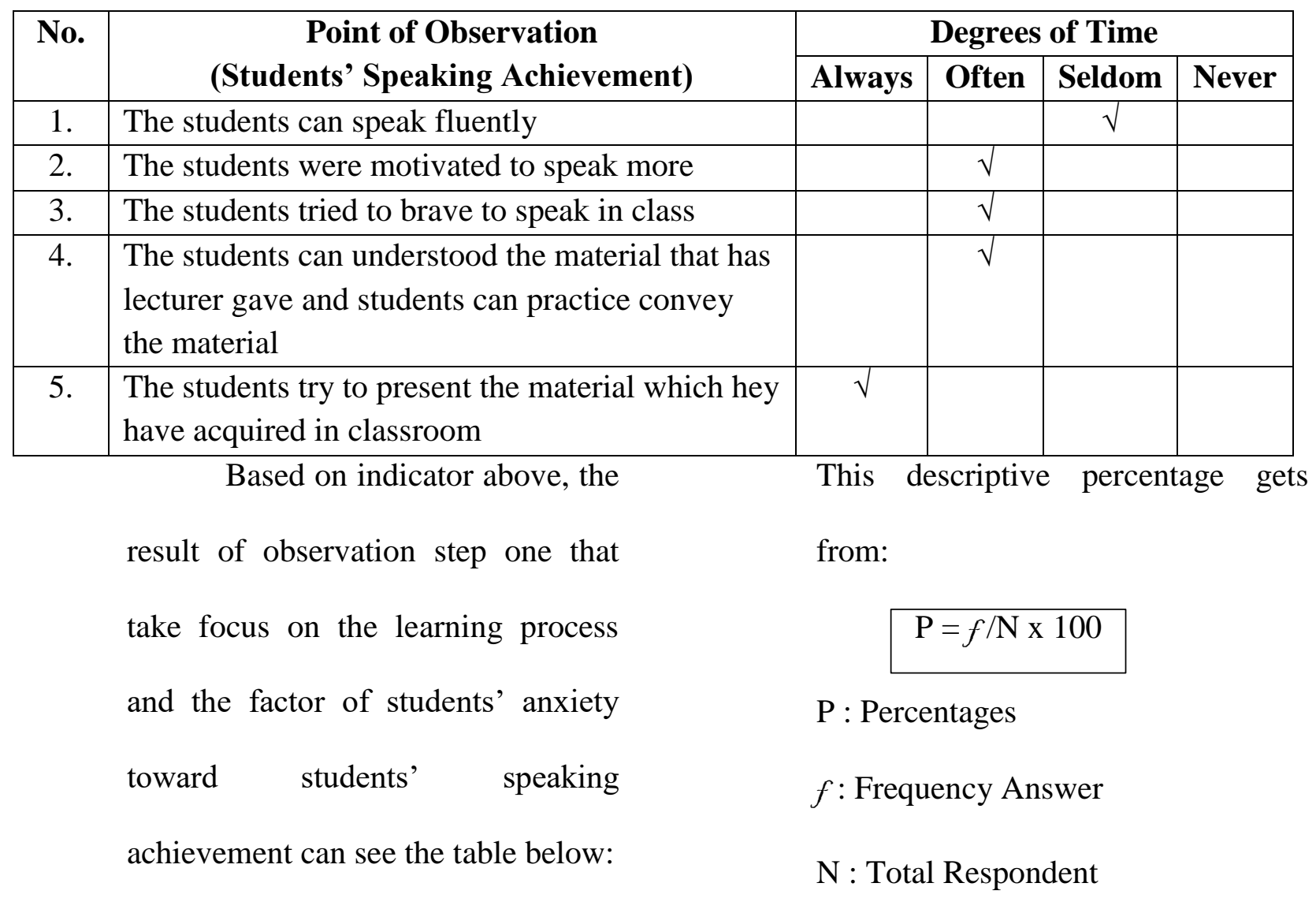

Table 5

The Percentage of Indicator Behavior in Speaking Classroom And The Factor of Students' Anxiety toward Speaking Achievement

\begin{tabular}{|c|l|c|c|c|c|c|}
\hline No. & \multicolumn{1}{|c|}{ Observation Aspect } & \multicolumn{3}{|c|}{ Degrees of Time } & \multirow{2}{*}{ Total } \\
\cline { 3 - 6 } & & Always & Often & Seldom & Never & $\%$ \\
\hline 1. & $\begin{array}{l}\text { The Indicator Students' } \\
\text { Behavior toward Speaking } \\
\text { Skill }\end{array}$ & $\begin{array}{c}4 \\
(36 \%)\end{array}$ & $\begin{array}{l}7 \\
(64 \%)\end{array}$ & & & 11 \\
\hline 2. & $\begin{array}{l}\text { The Factor of Students' } \\
\text { Anxiety toward Speaking } \\
\text { Achievement }\end{array}$ & $\begin{array}{c}1 \\
(20 \%)\end{array}$ & $\begin{array}{c}3 \\
(60 \%)\end{array}$ & $\begin{array}{c}1 \\
(20 \%)\end{array}$ & & 5 \\
\hline
\end{tabular}


b. Lecturer's Interview

The next step that the writer does to fulfill the observation in this research is interviewing the speaking lecturer. Some questions the writer has given to the speaking lecture are:

1. How do students respond when learning to speak

English?

Answer:

Their response was very good and enthusiastic, because by obtaining a speaking course they could express their ideas, skills, and daily experiences in English by means of oral practice.

2. What are the difficulties that exist when speaking learning?
Because of their different backgrounds, from different regions and tribes, sometimes when speaking practice is constrained in reciting English vocabulary that is still carried by their mother tongue, especially Sundanese with their unique dialect and do not recognize the sound / $\mathrm{f} /$, but so far their ideas continue to develop when presenting or performing in English. The obstacle that sometimes arises also is the limited mastery of vocabulary, so although there are many ideas that want to be expressed when speaking practice, the limitations of vocabulary also affect the quality of speaking. 
3. Do students feel not confidence when speaking English in front of the class?

Answer:

Actually, I am confused about answering this question, because the impact of this pandemic requires me and my students to research with a fully online system for one semester, so for students' confidence when class performance is lacking, so I can identify optimally, but during learning this online system I observe that almost all of my students have a high level of confidence in learning to speak, I can see it from the video assignments sent.

4. How do you deal with students who are nervous and anxious when speaking

English?

Answer:

Giving feedback at the end of their performance, by motivating continuously, giving advice not to compare their weaknesses with the strengths of other students, they should only compare their current abilities with previous meetings (is there an increase or setback).

5. What strategies are used to stimulate students to speak English in front of the class?

Answer:

Presentation Strategy (every meeting they have to present in English), conversation, telling stories, role play, discussion, learning 
using E-Learning (video), combining speaking and pronunciation, showing videos relevant to the material (which I recommend my lecturer, Mr. $\mathrm{D}$, because he is a native American).

6. According to you, what are the causes of students feeling anxiety when speak English?

Answer:

Lack of self-habit of speaking English when in school, so when in college a little bit shocked by oral English practice, because at school more focused on grammar, feel they do not have enough ideas or vocabulary to speak English so they are reluctant to start, besides that the shyness factor is excessive so that even though they have enough ideas and vocabulary to speak, it would be hampered because of that shame.

In the interview above, the writer can conclude that there are still many students who have limited mastery of vocabulary in English so that it is difficult to speak English, the pronunciation or pronunciation of English is still lacking because their daily language is Indonesian or mother tongue. Embarrassment and selfconfidence also inhibit students' development in speaking English in the speaking class. However, students have good enthusiasm when learning speaking takes place. 


\section{The Result of Interview}

Interview was being the step to do in this research. The interview would be given to the students, and the interview planed on $12^{\text {nd }}$ May 2020 . The amount of interviewed questions was five questions. The participant was taken eleven students that had being interviewed. Here was the result of interviewed.

For question number one "what do you feel when you are in the speaking class?", which can be concluded by the writer is Many students feel anxious and nervous when the speaking learning begins, worrying about what assignments would be given from the lecturer for them to do because, every meeting at speaking learning is going forward to make a presentation about a material, some students feel unprepared and nervous about doing it without preparation. There are some students who still enjoy and do not care about anything that happen when speaking learning.

After that, the writer asked about "what factors make you feel nervous and anxious when speaking English?", they answered that there were many factors that could cause nervousness and anxiety to arise when speaking English in front of the class, ranging from limited mastery of vocabulary, grammar, and pronunciation. There are also students who answer because of the unbelief factor that makes them embarrassed so nervous when speaking English. Many students feel anxious and nervous when speaking English in front of the class due to lack of prior preparation when the lecturer calls their names to come forward the class, they already feel their hearts beating and immediately confused what they should do if previously without preparation, pronunciation 
Volume 3 No. 2, August 2020

Universitas Banten Jaya

mistakes also make they are afraid to try to string words in English.

After getting answers from students who are very diverse, the writer asked about "how do you overcome that anxiety when speaking English in front of the class?", they answer with answers as diverse as; some answer by convincing yourself that you will be able to speak English, change your mindset so that you are not dependent on the translation application so you can get used to spontaneously speaking English directly, relax your body by breathing long breath, listening to music and drinking, with assuming that they are talking to themselves so as not to be nervous and some are dealing with it in a unique way that is bypassing the lips to keep them relaxed and relaxed.

When the writer asks about "when you speak English in front of the class, what body reactions do you feel?", some
P-ISSN 2623-0062

E-ISSN 2622-9056

students feel like their hands are trembling, they suddenly want to pee and some even feel hot and cold in their bodies, This can happen if there is a lack of preparation when they want to speak English in front of the class.

On the last question the writer asked about "how do you feel, when your friends laugh at your mistakes in speaking English in front of the class?", most of them answered that it did not matter but would be used as a reference to be able to fix it, some students sometimes feel offended when their friends laugh at their mistakes, because it is not funny and not to be laughed.

\section{The Result of Questionnaire}

There are 23 students each student given 30 questions the same, where questionnaire the named Scala Likert, of the result it has been in calculate by the 
writer for question number 1-30 below.

Here the result of questionnaire:

Table 6

\section{Result Percentage of Questionnaire}

\begin{tabular}{|c|c|c|c|}
\hline No. & Question & Percentage & Category \\
\hline 1 & $\begin{array}{l}\text { Students never feel quite sure of theirself } \\
\text { when they are speaking in my foreign } \\
\text { language class. }\end{array}$ & $61 \%$ & Agree \\
\hline 2 & $\begin{array}{l}\text { Students do not worry about making } \\
\text { mistakes in language class. }\end{array}$ & $65 \%$ & Agree \\
\hline 3 & $\begin{array}{l}\text { Students tremble when they know that they } \\
\text { are going to be called on in language class. }\end{array}$ & $63 \%$ & Agree \\
\hline 4 & $\begin{array}{l}\text { It frightens me when students do not } \\
\text { understand what the lecturer is saying in the } \\
\text { foreign language. }\end{array}$ & $56 \%$ & Neutral \\
\hline 5 & $\begin{array}{l}\text { During language class, students find their } \\
\text { self thinking about things that have nothing } \\
\text { to do with the course. }\end{array}$ & $56 \%$ & Neutral \\
\hline 6 & $\begin{array}{l}\text { Students keep thinking that the other } \\
\text { students are better at languages than they } \\
\text { are. }\end{array}$ & $77 \%$ & Agree \\
\hline 7 & $\begin{array}{l}\text { Students usually at ease during tests in my } \\
\text { language class. }\end{array}$ & $59 \%$ & Neutral \\
\hline 8 & $\begin{array}{l}\text { Students start to panic when they have to } \\
\text { speak without preparation in language class. }\end{array}$ & $76 \%$ & Agree \\
\hline 9 & $\begin{array}{l}\text { Students worry about the consequences of } \\
\text { failing their foreign language class. }\end{array}$ & $73 \%$ & Agree \\
\hline 10 & $\begin{array}{l}\text { Students do not understand why some people } \\
\text { get so upset over foreign language classes. }\end{array}$ & $72 \%$ & Agree \\
\hline 11 & $\begin{array}{l}\text { In language class, students can get so } \\
\text { nervous they forget things they know. }\end{array}$ & $65 \%$ & Agree \\
\hline 12 & $\begin{array}{l}\text { It embarrasses students to volunteer answer } \\
\text { in students language class. }\end{array}$ & $57 \%$ & Neutral \\
\hline 13 & $\begin{array}{l}\text { Students get upset when they do not } \\
\text { understand what the lecturer is correcting. }\end{array}$ & $61 \%$ & Agree \\
\hline 14 & $\begin{array}{l}\text { Even if students well prepared for language } \\
\text { class, they feel anxious about it. }\end{array}$ & $61 \%$ & Agree \\
\hline
\end{tabular}




\begin{tabular}{|c|c|c|c|}
\hline 15 & $\begin{array}{l}\text { Students often feel like not going to their } \\
\text { language class. }\end{array}$ & $50 \%$ & Neutral \\
\hline 16 & $\begin{array}{l}\text { Students feel confident when they speak in } \\
\text { foreign language class. }\end{array}$ & $53 \%$ & Neutral \\
\hline 17 & $\begin{array}{l}\text { Students afraid that my language lecturer is } \\
\text { ready to correct every mistake they make. }\end{array}$ & $66 \%$ & Agree \\
\hline 18 & $\begin{array}{l}\text { Students can feel my heart pounding when } \\
\text { they are going to be called on in language } \\
\text { class. }\end{array}$ & $71 \%$ & Agree \\
\hline 19 & $\begin{array}{l}\text { The more students research for a language } \\
\text { test, the more confused I get. }\end{array}$ & $63 \%$ & Agree \\
\hline 20 & $\begin{array}{l}\text { Students do not feel pressure to prepare very } \\
\text { well for language class. }\end{array}$ & $59 \%$ & Neutral \\
\hline 21 & $\begin{array}{l}\text { Students always feel that the other students } \\
\text { speak the foreign language better than they } \\
\text { do. }\end{array}$ & $77 \%$ & Agree \\
\hline 22 & $\begin{array}{l}\text { Students feel very self-conscious speaking } \\
\text { the foreign language in front of other } \\
\text { students. }\end{array}$ & $71 \%$ & Agree \\
\hline 23 & $\begin{array}{l}\text { Language class moves so quickly, students } \\
\text { worry about getting left behind. }\end{array}$ & $65 \%$ & Agree \\
\hline 24 & $\begin{array}{l}\text { Students feel more tense and nervous in their } \\
\text { language class than in my other classes. }\end{array}$ & $57 \%$ & Neutral \\
\hline 25 & $\begin{array}{l}\text { Students get nervous and confused when } \\
\text { they are speaking in my language class. }\end{array}$ & $62 \%$ & Agree \\
\hline 26 & $\begin{array}{l}\text { When Students on their way to language } \\
\text { class, they feel very sure and relaxed. }\end{array}$ & $73 \%$ & Agree \\
\hline 27 & $\begin{array}{l}\text { Students get nervous when Students do not } \\
\text { understand every word the language lecturer } \\
\text { says. }\end{array}$ & $73 \%$ & Agree \\
\hline 28 & $\begin{array}{l}\text { Students feel overwhelmed by the number of } \\
\text { rules you have to learn to speak a foreign } \\
\text { language. }\end{array}$ & $62 \%$ & Agree \\
\hline 29 & $\begin{array}{l}\text { Students am afraid that the other students } \\
\text { will laugh at me when they speak the foreign } \\
\text { language. }\end{array}$ & $63 \%$ & Agree \\
\hline 30 & $\begin{array}{l}\text { Students get nervous when the language } \\
\text { lecturer asks which they haven't prepared in } \\
\text { advance. }\end{array}$ & $81 \%$ & $\begin{array}{l}\text { Strongly } \\
\text { Agree }\end{array}$ \\
\hline
\end{tabular}




\section{Percentage of Questionnaire}

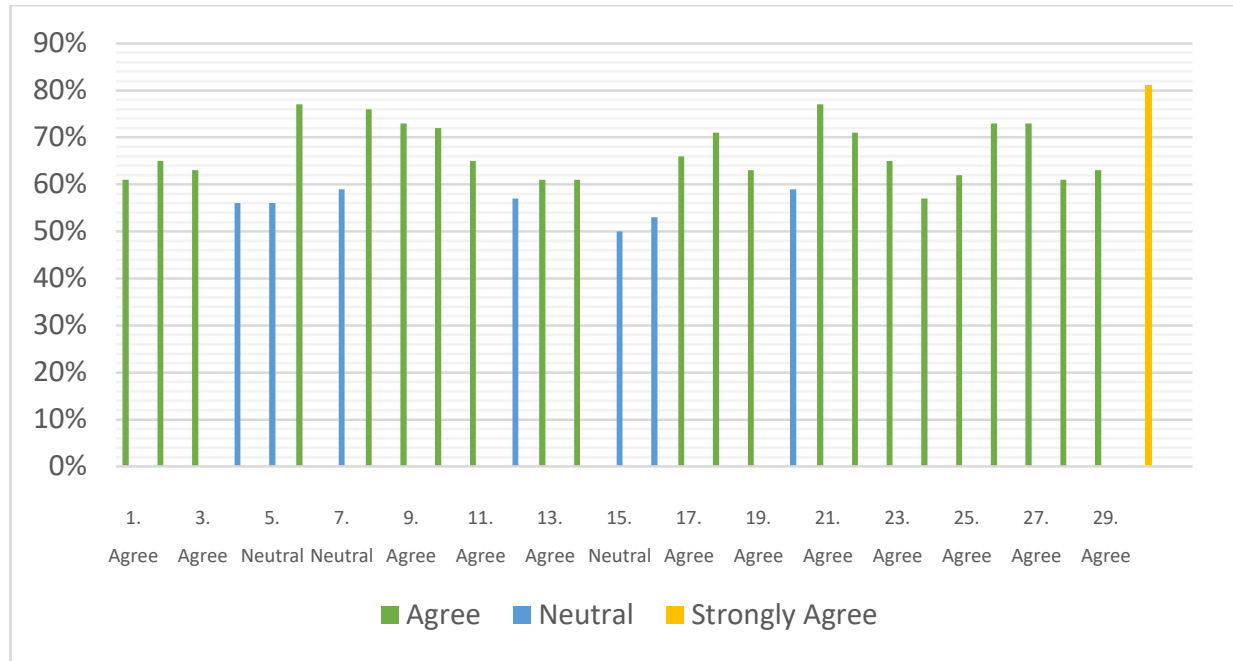

\section{DISCUSSION}

The finding suggested the level anxiety and several factors that possibly contribute to the students' anxiety at their speaking learning.

\section{The Level Anxiety at Speaking}

\section{Learning}

The result of the questionnaire in response students about anxiety it was high.

By calculation used the formula in the thirty statement, it is evident that that level anxiety in the students second semester in English Education Department is $65 \%$ at speaking learning, students' experiences share a lot of data about student anxiety in questionnaire and interview. They offer knowledge about what can contribute to their anxiety and what teachers can try to reduce that anxiety. In other words, students can share valuable data about their anxiety in dialogue education. Therefore, it means to use their knowledge to produce a more relaxed area. Student speaking anxiety is something that must be considered, not only from the students 
Volume 3 No. 2, August 2020

Universitas Banten Jaya

themselves but from the lecturer can also cause anxiety to arise.

\section{Factors Contribute to Anxiety}

It also indicated that those factors come from the students. Based on the findings, the factors that contribute to anxiety could be classified as follows:

\section{a. Students' belief about the language learning}

Certain beliefs are also found as factors that can affect student anxiety. Many of them say that English is a difficult subject. They always assume that they have difficulty when speaking English correctly and fluently. To understand the explanation in the learning class speaking also they feel difficulties. The many rules that exist when speaking English make them feel overwhelmed to understand everything. The vocabulary and
P-ISSN 2623-0062

E-ISSN 2622-9056

grammatical that they complain about when speaking English, according to them the two are very difficult to understand.

\section{b. Lack of preparation}

Preparation when speaking English is also a factor that affects students' speaking anxiety. During the interview, many students said that if they were called to speak English in front of the class without any preparation, they would feel nervousness and anxiety because they did not know what to say when speaking English. Making preparations is a mandatory thing they must do before speaking English in front of the class, during the interview there is one student who said that the preparation he usually does is to write the words what he wants to say, and then he will make the writing memorized so 
Volume 3 No. 2, August 2020

Universitas Banten Jaya

that keep fluent in English. Some say

the preparation is done in a unique

way, namely by overcoming anxiety

by doing some mouth heating before

speaking English in front of the class.

\section{c. Speaking in front of the class}

Most participants answered that they were very worried when they had to speak in front of the class. They also answered that they often felt nervous and anxious when the lecturer asked them to speak in front of the class. While some students map that they feel very panicked when they have to speak in front of the class. Many students also said that when the lecturer was asking a question, they would feel very anxious and worried if they could not answer the question.
P-ISSN 2623-0062

E-ISSN 2622-9056

Then when speaking in front of the class, they feel uncomfortable because all students pay attention to it which makes them more nervous. They also feel afraid that if they make a mistake, the lecturer will correct the error and reveal their weaknesses. Their sense of disbelief is very large because they assume the lack of mastery of grammar and pronunciation in English.

\section{CONCLUSION}

Based on the research conducted in second semester of English Education Department at University of Banten Jaya in academic year 2020, it can be concluded students Agree that anxiety can be a important factor at speaking learning and there are various factors that may contribute to their anxiety.

1. The result of the questionnaire is writer can conclude that response students about anxiety can be a factor in speaking 
Volume 3 No. 2, August 2020

Universitas Banten Jaya

learning was agree. Students feel nervousness and anxiety when speaking English in front of the class, students are anxious to start conversations in English and students are anxious when speaking without preparation in front of the class. By calculation used the formula, it is evident that students agree (65\%) that anxiety can be a factor in speaking learning. Student speaking anxiety is something that must be considered, not only from the students themselves but from the teacher can also cause anxiety to arise.

2. According to students' response from interview, there are various fators that may contribute to their anxiety. There are at least three factors which are found in this research, there are: speaking in front of the class, incomprehensible input, and lack of preparation. The sources of these factors are come from the students. Moreover, those factors were discussed
P-ISSN 2623-0062

E-ISSN 2622-9056

in this research, which deepened our understanding of speaking anxiety.

\section{REFERENCES}

Bailey, K.M. 2006. Issues in teaching speaking skills to adult ESOL learners. NJ: Lawrence Erlbaum Associates, 25.

Bashir, M., Azeem, M., \& Dogar, A.H (2011) Factor Effecting Students' English Speaking. British Journal of Arts and Social Sciences, 2 (1), 38.

Brown, H. D. 2001. Teaching by Principles: An Interactive Approach to Language Pedagogy. San Fransisco: State University.

Brown, H. D. 2011. Language Assessment Principle and Classroom Practices. Chapter 1: Testing, Assesing and Teaching.

Brown, H. D. 2011. Language Assessment Principle and Classroom Practices. Chapter 7: Assesing Speaking.

Cutler, Howard C. (2004). The Art of Happiness

Fulcher, G. (2003). Testing Second Language Speaking.

Harlow: Longman/Pearson

Education, 95

Halgin R.P, \& Whitbourne K. Susan. (2007). Abnormal Psychology: Clinical Perscpectives on Psychological Disorder, 148.

Horikawa, Masami, \& Yagi, Akihiro. (2012) The Relationships among Trait Anxiety, State Anxiety and The Goal 
Volume 3 No. 2, August 2020

Universitas Banten Jaya

Performance of Penalty Shoot. Journal plus one 7 (4).

Hurd, S., (2007) Anxiety and non-anxiety in a distance language learning environment: the distance factor. 487-508.

K. Wiedemman (2001) Anxiety and Anxiety Disorders. International Encyclopedia of the Social \& Behavioral Sciences.

Leal P. Caldeira, Goes T. Costa, Silva, L. Callos, Silva, F. Teixeira (2017) Trait vs State Anxiety in Different Threathing Situation. Trends Psychiatry Psychoter. 39 (3)

Liu, M., \& Huang. W. (2011) An Exploration of Foreign Language Anxiety and English Motivation Education. Research International, 1-8.

Lucas, R.I., Miraflores, E., \& Go, D. (2011). English Language Learning Anxiety among Foreign Language Learners in the Philippines. Philippine ESL Journal, 7. 94-119.

Martin, J.T (2019) English Speaking Anxiety of Physical Education Major Students. Asian EFL Journal Research Articles, 23 (3), 106.

Nuraida, Ida. 2018. "First Language Acqusition of Eighteen-Month Twins." The Asian EFL Journal 20(10): 249. -. 2019. "The Asian EFL Journal Volume 23, Issue 3 . 2 Senior Editors :" 23(3).

Nuraida, Ida. 2018. "First Language Acqusition of Eighteen-Month Twins." The Asian EFL Journal 20(10): 249.

Editors :" 23(3).

Ormrod, J. E. (2011) Educational Psychology: Developing Learner. Boston: Pearson Education Inc.

Krashen's, S. Schutz Ricardo Theory of Second Language Acquisition, 2013.

Robbins, Stephen P. (2000). Teori Organisasi. Terjemahan Yusuf Udaya. Jakarta: Acam, 494-495.

Vagg PR, Speilberger CD, O’Hearn Jr Tp. Ls (1980) The states-Trait Anxiety Inventory Multidimensional? 1. 207.

Woodrow, Lindy (2006) Anxiety and Speaking English as a Second Language. RELC Journal, (37). 309. 